\title{
MEDICINE
}

\section{YEARS EXPERIENCE OF INTERLOCKING INTRAMEDULLARY METALLIC-POLYMERIC OSTEOSYNTHESIS IN TREATMENT OF 1200 PATIENTS WITH SHAFT FRACTURES}

Vasiuk V. Le., PhD in Traumatology, Professor,

Kovalchuk P. Ye., PhD in Traumatology, Assoc. Professor,

Zinchenko A. T., PhD in Traumatology, Assoc. Professor,

Tulyulyuk S. V., assistant,

Department of Traumatology and Orthopedics

Higher State Educational Establishment of Ukraine

"Bukovinian State Medical University», Ukraine

DOI: https://doi.org/10.31435/rsglobal_ws/31082019/6629

\section{ARTICLE INFO}

Received: 10 June 2019

Accepted: 12 August 2019

Published: 31 August 2019

\section{KEYWORDS}

fractures,

metal polymeric fixation devices, interlocking osteosynthesis.

\begin{abstract}
The article comprises the main principles of interlocking intramedullary metallic-polymeric nailing (IIMPN) and the experience of its implementation in 1200 cases of shaft fractures during the period of 40 years. Three generations of metallic-polymeric nails and techniques for closed, semi-closed and open IIMPN were designed. The nails can successfully be interlocked with proximal and distal bone fragments without an intraoperative X-ray control. Therefore, the operation can be made in any hospital capable of surgical treatment of fractures. Unlike interlocking metallic nailing, the dynamic variant of IIMPN makes the additional operation of dynamization unnecessary. CMPN-3 and CMPN-2 nails have options of intraoperative axial and lateromedial compression between fragments, which is impossible in interlocking metallic nailing. The carving conjunction between screws and polymer, which flexibility is close to that of the bone, excludes critical concentration of tensions and considerable dynamic loadings, and therefore prevents fractures of the interlocking screws. Good follow-up results were obtained in $94.2 \%$ patients.
\end{abstract}

Citation: Vasiuk V. Le., Kovalchuk P. Ye., Zinchenko A. T., Tulyulyuk S. V. (2019) 40 Years Experience of Interlocking Intramedullary Metallic-Polymeric Osteosynthesis in Treatment of 1200 Patients with Shaft Fractures. World Science. 8(48), Vol.2. doi: 10.31435/rsglobal_ws/31082019/6629

Copyright: (C) 2019 Vasiuk V. Le., Kovalchuk P. Ye., Zinchenko A. T., Tulyulyuk S. V. This is an openaccess article distributed under the terms of the Creative Commons Attribution License (CC BY). The use, distribution or reproduction in other forums is permitted, provided the original author(s) or licensor are credited and that the original publication in this journal is cited, in accordance with accepted academic practice. No use, distribution or reproduction is permitted which does not comply with these terms.

Interlocking intramedullary metallic-polymeric nailing (IIMPN) was first introduced in 1960 by the godfather of intramedullary osteosynthesis G. Kuntscher to treat comminuted fractures of the femoral bone [10, 312-317].

Further improvement of the method in 60-70-s of the last century by the German and French traumatologists K. Klemm, W.D. Shellmann [11, 568-575] and I. Kempf, A. Grosse [12, 709-720] made a scientific breakthrough in the solution of problems in surgical treatment of diaphyseal fractures of the femur and leg. Closed nailing has become widespread in all the developed countries of the world.

In 1985 I.Kempf, A.Grosse published results of closed interlocking nailing of fresh femoral fractures in 436 patients including 65 with open fractures. Postoperative osteomyelitis occurred only in $0,45 \%$ of those being operated on. Similar data are suggested by other authors as well [12, 709-720]. 
The following steps to improve intramedullary nailing included rejection from drilling-out of the intramedullary canal, transition to monolithic screws of a smaller and changeable diameter. Such innovations laid the foundations for the use of interlocking osteosynthesis by means of screws without drilling-out of the intramedullary canal in the treatment of open fractures, since their application corresponds to the principles of biological (mini-invasive) osteosynthesis completely [13, 1569-1590; 14, 683-689].

The following stages have become the evolution of intramedullary osteosynthesis:

1. Unstable intramedullary osteosynthesis by means of unimproved screws (Bogdanov, Zaloznyi et al.).

2. Intramedullary osteosynthesis with massive screws followed by drilling-out of the intramedullary canal, search for an optimal shape of the transverse section (Kuntscher, Dubrov, Syvash).

3. Attempts to design anchor fixation devices (screws developed by Pavelik, PanchenkoOstapchuk, Fishkin).

4. Interlocking intramedullary osteosynthesis with drilling-out of the intramedullary canal (Kuntscher, Rublenyk, Bliskunov, Bytchuk).

5. Closed interlocking intramedullary osteosynthesis with screws of a smaller size without drilling-out the intramedullary canal.

6. Closed interlocking intramedullary osteosynthesis with metal screws of a changeable diameter without drilling-out the intramedullary canal.

7. Interlocking intramedullary metallic-polymeric nailing with screws of a changeable diameter without drilling-out the intramedullary canal.

At the Department of Traumatology, Orthopedics and Neurosurgery, Bukovinian State Medical University, since 1978 Professor I.M. Rublenyk and his pupils and collaborators have been conducting an intensive research and scientific work in the field of development of technologies of interlocking intramedullary metallic-polymeric nailing (IIMPN), which appeared to be better than the world innovations in many parameters. Three generations of metallic-polymeric fixation devices and a set of instruments for surgery have been created, the technologies of open, semi-open and closed IIMPN, its static, dynamic and detention variants have been developed. IIMPN technologies are developed for surgical treatment of the femoral, tibia and humeral bones.

879 patients were operated on during the period from 1978 to 2018, and fundamental biochemical and clinical-radiological examinations were performed. Their results are protected by more than 30 USSR patents, 2 patents and 6 declaration patents of Ukraine and abroad, reports at the congresses and conferences.

Objective: to publish 40-year experience of use of the interlocking intramedullary metallicpolymeric nailing in the treatment of shaft fractures in 1200 patients.

Materials and methods.

Technical aids. The most frequently used metallic-polymeric constructions used for osteosynthesis of diaphyseal fractures of the femur and tibia bones are described below.

Compressive metallic-polymeric fixation device CMPF-2 (USSR author's certificate №806019 - Fig. 1) looks like a hollow round metallic frame 1, through-openings are made along the whole length in it 2 , filled with polyamide- 12 .

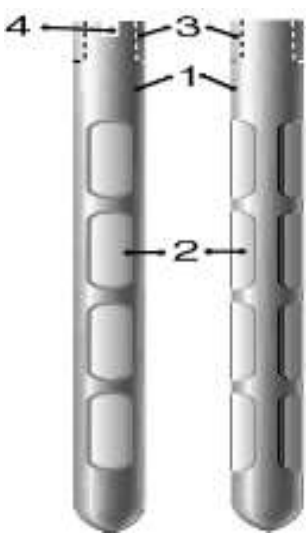

A

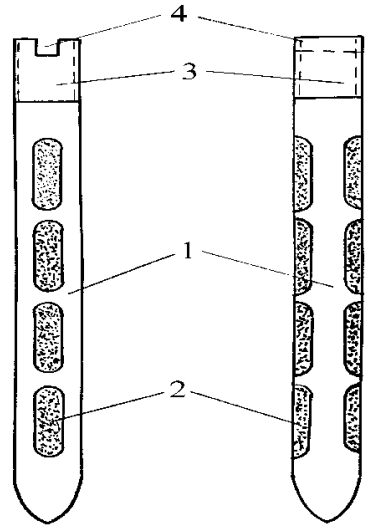

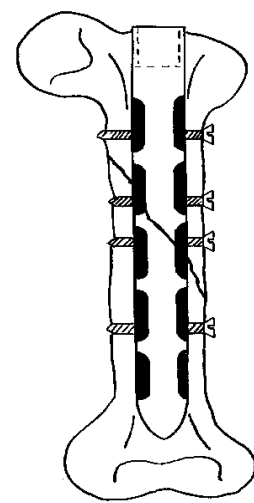

$\mathrm{B}$

Fig. 1 CMPF-2 diagram (A) and CMPF-2 osteosynthesis outline (B). 
This design enables to interlock the fixation device with the bone in case of diaphyseal fractures on any level, creating wider possibilities to use the construction effectively.

The internal thread 3 is located at the proximal end of the metallic frame. By means of this thread the fixation device is connected with the instrument applied in case of introduction and removal the fixation device from the bone. The slot 4 is made on the face of the fixation device in the same plane with the through longitudinal openings for correct orientation of interlocking screws. The transverse interfragmental compression is achieved by means of interlocking screws inserted through the fragments and polymeric parts of the fixation device perpendicular to the longitudinal axis of the bone (Fig. 1).

CMPF-3 (USSR author's certificate №946531 - Fig. 2) is made in the shape of a round metallic rod 1. Its proximal end closes in the threaded tail 2 with the slot on the face 3. De-rotary blade in the shape of trapezium 4 with the base on the rod is located under the threaded tail. With the aim to reduce bone injury in case of insertion and removal of the fixation device free sides of the blade are pointed.

When the fixation device is inserted into the intramedullary canal, de-rotary blade comes deeper into the spongy substance of the bone proximal metaepiphysis. This method excludes the possibility of scrolling of the fixation device in the central fragment and does not prevent dynamic compression occurring during graduated weight bearing on the extremity. On the distal end of the rod in the same plane with the slot and de-rotary plate a longitudinal through opening (5) is made filled with polyamide-12. Interfragmental compression is achieved by means of a compressive nipple screw (6), which is screwed on the threaded tail after interlocking of the fixation device in the distal fragment (Fig. 2).

To achieve minimal traumatic consequences of surgery and the least possible of infectious complications, interlocking intramedullary metallic-polymeric fixation devices for closed osteosynthesis were developed.

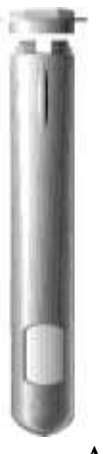

A

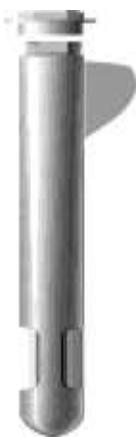

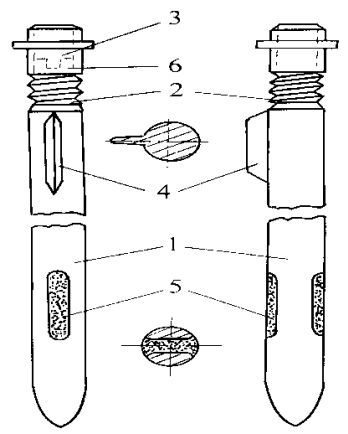

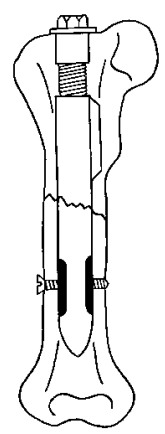

B

Fig. 2. CMPF-3 diagram (A) and CMPF-3 osteosynthesis outline (B).

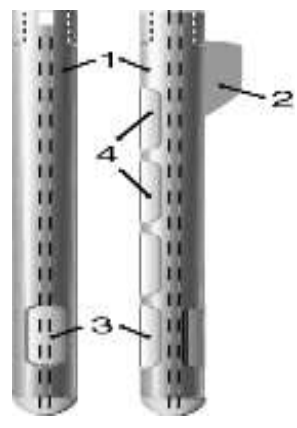

$A$

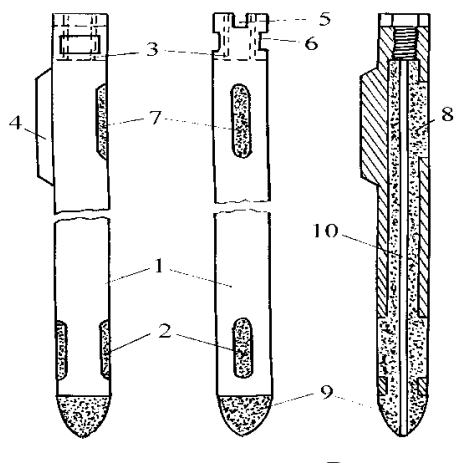

$B$

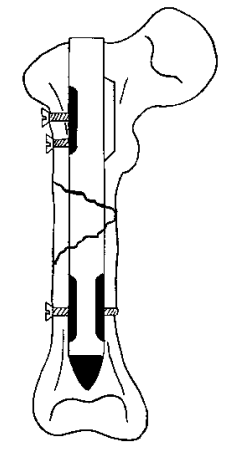

(1)

Fig. 3 CMPF-6 diagram (A) and the outline of osteosynthesis by means of CMPF-6 (B).

Compressive metallic-polymeric fixation device CMPF -6 (Fig. 3) is made in the shape of a round hollow metallic body 1. A through longitudinal opening 2 is made on its distal end. The proximal end contains internal thread 3, de-rotary blade 4, slot 5 and disks 6 . The opening 7 is made on an opposite side on the level of the de-rotary blade. The cavity of the metallic body is filled with the polymer 8 along the whole length of the internal thread. On the distal end the polymer goes beyond the body borders forming the tip 9. A longitudinal directing canal 10 is made inside of the 
polymer. After the fixation device is inserted into the bone fragments it is interlocked with screws on the level of the longitudinal openings (Fig. 3).

The interlocking intramedullary fixation device of the seventh model is developed and introduced for osteosynthesis of femoral head fractures - CMPF-7 (Declaration patent of Ukraine for invention № 34297 A MKB 6 A 61B 17/18, 2001), consisting of a round hollow rod of a changeable diameter 1 , in which through openings 2 and 3 are made filled with polyamide-12 (Fig. 4). On the proximal end of the fixation device there are disks 4, opening 5, slot 6 , and internal thread 7.

Osteosynthesis with the device is performed by means of the closed method without denudation of the site of fracture under control of an electron-optical converter (EOC) (Fig. 4).

For this purpose a patient is placed on a traction table resting into the perineum and fixation of both feet. All the kinds of dislocation are eliminated by a lengthwise traction, little deviation (to the angle of $15^{\circ}$ ) with a zero rotation as a rule. The major trochanter is trephined through the cuts in the skin $4-5 \mathrm{~cm}$ long, the intramedullary canal is calibrated with a drill. The suggested fixation device is inserted into the bone prepared by the method described. The wire 9 is inserted into the femoral head through the conductor opening 10 and fixation opening 5 (Fig. 2.10), placing polymeric portions of the fixation device in the same plane with the femoral neck. Two canals are drilled in the femoral head and neck at the angle of $130^{\circ}$ to the longitudinal axis of the femur by means of the conductor 8 in the polymeric portion of the fixation device 2 . Two more canals are drilled in the transverse direction through the femur and polymeric portion 3 . Thread is tapped in the received canals and screws 11 and 12 are inserted. The wire 9 and the conductor 8 are removed, and stitches are applied onto the skin.
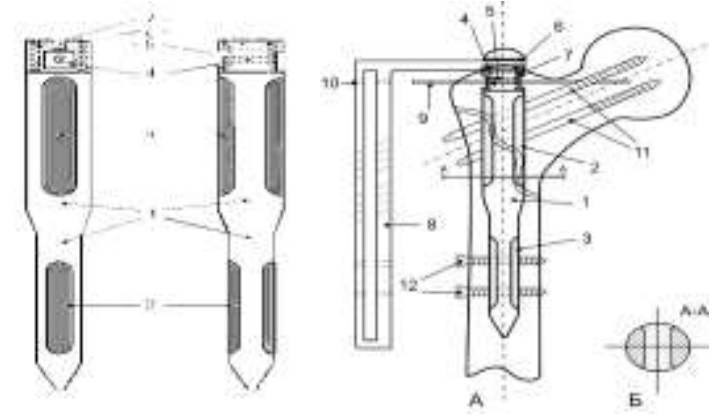

Fig. 4 CMPF-7 diagram and CMPF-7 osteosynthesis outline

Clinical-biochemical variants of IIMPN. Depending on possible loading of a regenerator after osteosynthesis and considering position of interlocking screws there are dynamic (Fig. 5 - A), static (Fig. $5-$ - $)$ and detention (Fig. 5 - B) variants of IIMPN.

CMPF-3 and universal BMPF-6 are used for dynamic variant. Metallic-polymeric fixation device is blocked with screws only in the distal fragment providing a high rotation stability of the "bone-fixation device" system in addition to de-rotary blade available in the proximal part of the fixation device. And loading of the extremity results in dynamic loading of the regenerator in the place of fracture (Fig. $5 \mathrm{~A}$ ).

Static variant of IIMPN assumes the use of CMPF-2, inserting interlocking screws through the line of fracture, as a rule, in case of osteosynthesis of oblique and spiral fractures. Under these conditions in case of oblique loading of the bone, dynamic loading of the regenerator in the place of fracture is excluded, since it is transmitted through the interlocking screws directly to the fixation device (Fig. 5-B).

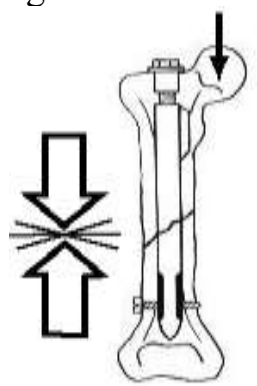

A

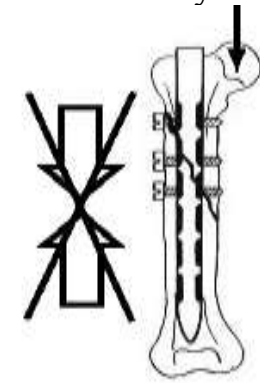

Б

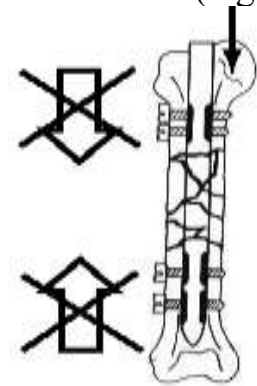

B

Fig. 5. Diagram of clinical-biochemical variants of IIMPN. $A$-dynamic; 5 - static; $B$-detention. 
Detention variant is a kind of static one, when interlocking screws are inserted on the level of the proximal and distal portions outside of the area of fracture. This variant is essential in case of multi-fragmental, comminuted fractures in order to prevent telescopic dislocation of fragments on the fixation device during longitudinal loading of the extremity (Fig. 5 B).

Characteristics of patients. During the period from 1978 to 2018 at the medical establishments of Chernivtsi, Khmelnytskyi, Dnipropetrovskyi regions 1200 surgeries were performed applying different variants of IIMPN. The age of patients was from 12 to 90 , an average age - 36,5. 782 patients were operated on for fresh fractures, 418 - due to their consequences (slow and irregular consolidation of fractures, pseudoarthrosis, and bone defects). Comminuted fractures were detected in $80 \%$ of patients. Disorders of reparative osteogenesis were found in $10,7 \%$ of patients.

Dynamic variant of IIMPN was applied in $91 \%$ of patients, static one - in 7,6\%, and detention one - in $2,4 \%$. The open variant of IIMPN was used in surgical treatment of $48,4 \%$ patients, semiopen - in $29,2 \%$, closed - in $22,4 \%$. Dynamization surgery was not performed in any case.

Clinical examples. Dynamic variant of IIMPN is indicated in cases when contact of the main fragments is preserved or it is restored during surgery.

Patient K., 32 years old, case history №12564, admitted on 8.12 .2000 with the diagnosis: closed comminuted fracture with large fragments of the left femur on the border of the upper and middle thirds with dislocation of fragments (Fig. 6-A). The patient was injured in a car accident. On 10.12.2000 compressive dynamic variant of the open IIMPN was performed by means of CMPF-3 with restoration of a supporting contact of fragments by two screws. A massive bone fragment was fixed to the distal fragment by means of these screws trans-cortically (Fig. 6 - B). Postoperative period was without complications, the wound healed by primary tension. On the $14^{\text {th }}$ day after surgery the patient was discharged from the hospital for out-patient treatment. In a month a gradual functional loading was started, and it was complete in 2,5 month after surgery. The patient was examined 4 months later. The function of the operated extremity was restored completely. Radiologic image of bony union is presented on Fig. 6 - C. The patient returned to his previous job.

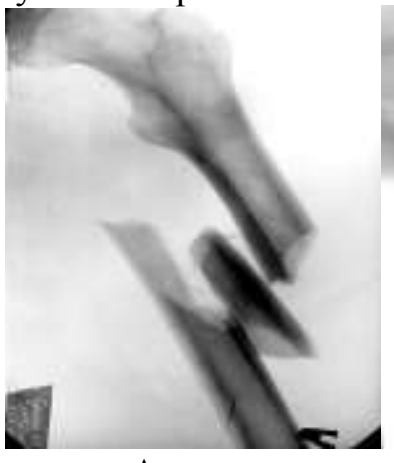

A

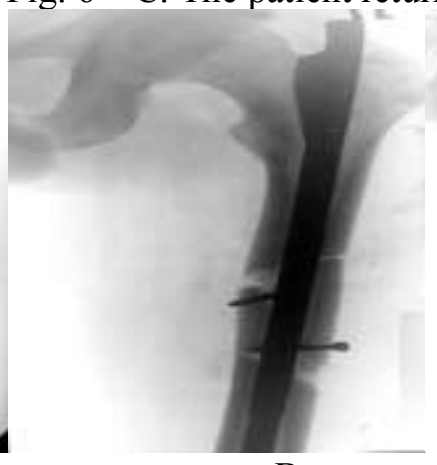

B

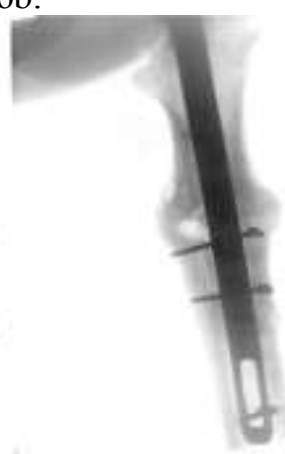

$\mathrm{C}$

Fig. 6. X-ray images of the patient $K$., 32 years of age, case history №12654. A-primary radiograph after getting injury; $B$ - three days after surgery; $C$ - three months after the open IIMPN by means of CMPF-3, dynamic variant.

Static variant of IIMPN. One of our observations is described below as an example of use of compressive static variant of the open IIMPN by means of CMPF-2.

Patient R., 47 years of age, case history №5079, was admitted to the clinic on 5.05.1995 due to closed spiral fracture of the left femur in the upper third with dislocation of fragments (Fig. 7. A). On 17.05.1995 compressive static variant of the open IIMPN was performed by means of CMPF- 2 (Fig. 7. B).

Postoperative period was without complications, measured loading was started in 1,5 month, complete loading - in 2,5 months. 3,5 months later the patient returned to his previous job. The patient was examined 1,5 year after surgery. He admitted periodical unpleasant sensations in the portion of the major trochanter above the extensive end of the fixation device. Radiological photo: complete restoration of the bone structure, the fixation device is removed (Fig. 7. C). 


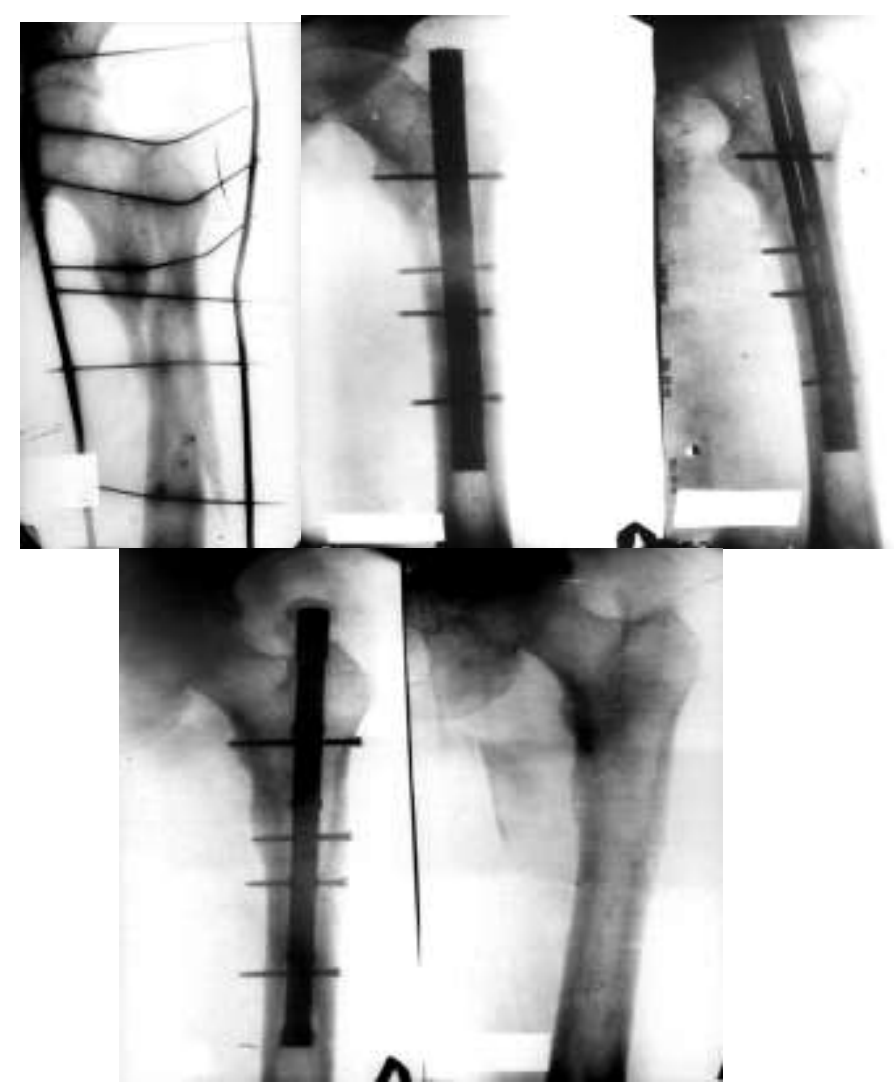

Fig. 7. X-ray of the left femur of the patient $R$. $A$ - on the day of admission,

$B$ - on the $4^{\text {th }}$ day after surgery of IIMPN by means of CMPF-2, static variant, $C-1,5$ year after surgery (before and after removal of the fixation device).

Detention variant of IIMPN. Crush fractures of the femur with a large area of destruction are the most complicated for surgical treatment. In these cases the use of traditional methods of intraosseous and bone osteosynthesis does not provide essential stability of fragments, and traumatic consequences of surgery increases the risk of suppurative complications considerably as well as disorders of the regeneration process.

Here are clinical examples of detention variant of IIMPN. Patient M., born in1958, traffic policeman was injured in a car accident on 12.01.96, resulting in multi-fragmental fracture of the upper and middle thirds of the right femur with dislocation of fragments (Fig. 7 - A). On 29.01.96 surgery was performed: IIMPN of the right femur with CMPF-2, statistical variant (Fig. $7-$ C). The fixation device was removed in a year (Fig. 7 - C). Restoration was achieved.

\section{Results and discussion.}

Remote consequences of treatment of the examined patients are indicative of positive results in $82,14 \%$ of patients, satisfactory results - in $12,5 \%$ of patients, and unsatisfactory results requiring further treatment are found in 5,36\% of victims. The frequency of satisfactory and unsatisfactory results is mainly caused by the character of injury.

Analysis and generalization of the results of IIMPN use demonstrated that metallic-polymeric interlocking fixation devices have a number of advantages in comparison with the interlocking screws suggested by Klemm-Schellmann, Grosse-Kempf, Smith-Richard, AO-ASIF.

The fixation device can be successfully blocked with the proximal and distal fragments of the femur without radiological control, which enables to use IIMPN in any traumatological department where fractures are treated by means of surgical treatment.

The dynamic variant of IIMPN spares patients additional dynamization surgery which is performed in case of interlocking osteosynthesis by means of metallic fixation device. The dynamic variant of IIMPN can be performed for the majority of patients with complicated fragmental fractures of the femur and leg on the terms of intra-operation restoration of the supporting contact of bone fragments. 
It becomes possible due to the de-rotary blade available in the proximal part of the metallicpolymeric constructions. It prevents reliably scrolling of the fixation device in the central fragment. In case of interlocking nailing by means of metallic screws the proximal interlocking screw is taken for rotation stability of the fixation device, which creates static variant of osteosynthesis in $75 \%$ of cases. And in case of static variant further surgery of dynamization is essential.

When CMPF-3 and CMPF-2 are used, in comparison with interlocking metallic nailing, in case of necessity inter-fragmental axial and lateral compression can be performed, which is an important factor to increase IIMPN stability.

Threaded connection of the screws with the polymeric material, which flexibility does not sustain considerable loading, and in case interlocking metallic screws are used blocking screws can be broken.

One of the advantages of metallic-polymeric constructions is great possibilities of IIMPN use in reconstruction surgery of the locomotor system, and in case of osteosynthesis of fracture consequences in particular (non-united, irregular united fractures and pseudoarthrosis).

Prospects of further studies. Interlocking metallic-polymeric constructions possess great potential possibilities for further improvement with the use of new bio-inert metal alloys and polymeric materials with high characteristics. It will enable to use IIMPN in the treatment of fractures of all the long bones.

Conclusions. Interlocking intramedullary metallic-polymeric nailing possess all the characteristics in order to take a noteworthy position among the range of surgical methods for the treatment of fractures and their consequences.

\section{REFERENCES}

1. Васюк В.Л. Клинико-экспериментальное обоснование металло-полимерного и полимерного остеосинтеза переломов большеберцовой кости: Дис. канд. мед. наук: 14.01.21. - Киев, 1990. - 201 с.

2. Васюк В.Л., Рубленик І.М. Можливості металополімерного остеосинтезу у лікуванні осколкових переломів стегна і гомілки // Вісник ортопедії, травматології та протезування. - 2003. - №1 - - С. 38-42.

3. Калашніков А.В. Розлади репаративного остеогенезу у хворих із переломами довгих кісток: Автореф. дис... доктора мед. наук: 14.01.21 / Інститут травматології та ортопедії АМН України. - К., 2003. - 35 с.

4. Лазарев А.Ф., Солод Э.И. Биологичный погружной остеосинтез на современном этапе // Вестник травматологии и ортопедии имени Н.Н.Приорова. - 2003. - №3. - С. 20-26.

5. Малоинвазивный остеосинтез в лечении пострадавших с множественными переломами костей верхних конечностей / Васюк В.Л., Рубленик И.М., Зинченко А.Т., Циркот И.М., Билык С.В. // Травма. - 2003. - Т. 4, №5. - С. 538-544.

6. Рубленик И.М. Металлополимерный и полимерный остеосинтез в лечении переломов длинных костей: Дис. докт. мед. наук: 14.00.22. - К., 1985. - 397 с.

7. Рубленик I.М., Васюк В.Л. Сучасні напрямки і проблеми заглибного остеосинтезу стегнової та великогомілкової кісток при діафізарних переломах та їх наслідках // Вісник ортопедії, травматології та протезування. - 2003. - №2. - С. 83-88.

8. Рубленик І.М., Ковальчук П.С. Закритий остеосинтез переломів великогомілкової кістки // Вісник ортопедії, травматології та протезування. - 2003. - № 1. - с. 48-50.

9. Рубленик І.М., Шайко-Шайковський О.Г., Васюк В.Л. Блокуючий інтрамедулярний металополімерний остеосинтез в лікуванні переломів кісток та їх наслідків. - Чернівці. - 2003. - 150 с.

10. Kuntscher G. Die biologishen Gesetze der Knochenbruh heilung. Teil II // Chirurg.-1961.-Bd.32.-N.7.-S.312-317.

11. Klemm K., Schellman W.B. Dynamische und statische Verriegelung des Marknagels // Mschr. Unfallheilk.-1971.-Bd.75.-N.12.-P.568-575.

12. Kempf I., Grosse A., Beck G. Closed Locked Intramedullary Nailing // J. Bone Jt. Surg.-1985.-Vol.67-A.N.5.-P.709-720.

13. Fracture fixation / Taljanovic M.S., Jones M.D., Ruth J.T., Benjamin J.B., Sheppard J.E., Hunter T.B. // Radiographics. - 2003. - Vol. 23, №6. - P. 1569-1590.

14. Mechanical borderline indications in the treatment of unreamed tibial nailing / Duda G.N., Mandruzzato F., Heller M., Schutz M., Claes L., Haas N.P. // Unfallchirurg. - 2003. - Vol. 106, №8. - P. 683-689. 